\title{
Palestine in Visual Representation: A Visual Semiotic Analysis of the Nakba
}

https://doi.org/10.33806/ijaes2000.21.1.6

\author{
Aladdin Assaiqeli \\ Universiti Pendidikan Sultan Idris, Malaysia
}

\begin{abstract}
Since its de facto creation, Israel has endeavoured to legitimize its existence and mystify the ethnic cleansing it perpetrated in 1948, systematically working to efface historic Palestine from the Arab and global public memory. Visual discourse plays a constitutive role in the construction and preservation of national themes. This paper, a critical discourse analysis of a corpus of visual representations, aimed to examine how visual representation serves to memorialize and reconstruct national themes, and so how this semiotic mode of representation can act as a form of counter-hegemonic discourse against attempts at the memoricide of the other and mystification of history. Using Kress and van Leeuwen's (2006) grammar of visual design as a framework for visual analysis, this social semiotic research analyzed the visual structure of a number of Nakba images to examine the role of visual representations in the memorialization of key Palestinian national themes, and so the reconstruction and preservation of historic Palestine. The study shows how visually represented national themes, such as ethnic cleansing and Right of Return, serve as a constant reminder of the Nakba, stressing their sociopolitical and emancipatory role in shaping the Palestinian collective consciousness about their past, present and future. Exploration of further visual signs can reveal more the function of visual and multimodal communication in the preservation of important national themes and role in national liberation.
\end{abstract}

Keywords: images, visuals, multimodality, visual communication, visual grammar, CDA, Nakba

\section{Introduction}

The Palestine Question is the most intractable contemporary form of colonization, and the only extant form of settler colonialism in the world today. It is the national trauma of the Palestinian people. It is the Palestinian refugee problem created in 1948 by Zionist radical procedures against the human geography and demography of Palestine, further exacerbated by the 1967 Israeli occupation of the rest of historic Palestine and the resultant displacement and dispossession of many more Palestinians. The Nakba or ethnic cleansing of Palestine, the extant Israeli occupation, and Israel's ongoing attempt at the memoricide of the Nakba constitute, in essence, what the Palestine Question is about, and underlie much of the ensuing spillover of regional wars and political unrest in the Middle East and probably the world at large (Assaiqeli 2019).

To legitimize and sustain its existence given such de facto creation on the rubble of Palestinian villages, the newly-found state of immigrants - Israel has developed an "ideologically-driven lexicon" (Walsh 2009: 26), which 
systematically misrepresents reality where ethnic cleansing becomes "voluntary exodus" or "transfer" or "War of Independence;" Palestine, "Israel;" the West Bank, "Judaea and Samaria;" Palestinians, "Israeli Arabs;" occupation, "settlement;" expansion, "natural growth; colonialism, "historical rights; occupied territories, "territories that are disputed;" settlements, "outposts;" freedomfighters, "terrorists;" the 1967 occupation of the rest of Palestine, "the Six Day War," etc. (Assaiqeli 2013).

A systematic, theory-based critical discourse analysis of a corpus of Nakba icons - naturalistic images visually/multimodally representing key Palestinian national themes - this paper aimed to demonstrate the role of Palestinian "visual language" or Nakba visual semiotics in confronting such Israeli attempts at the whitewashing of the original landscape and obliteration of the Palestinian memoryscape, and so their commemorative emancipatory function. The paper sought to show the role of visual discourse in reconstructing the Nakba or the ethnic cleansing of Palestine, making the memory of this event alive all the time. It examined the afterlife effect of images - how visual representations reconstruct national themes, and so how they counteract systematic and institutionalized attempts at the memoricide of the other and misrepresentation of reality. This study, in particular, sought to reveal how certain motivated iconic visual signs have evolved in Palestinian iconography or visual discourse to capture and represent important Palestinian national themes such as homelessness, rootedness, tenacity for return, historical and spiritual connection, etc.

The time for this study is ripe as the attempts to obliterate Palestine from the Arab and global public memory have intensified recently, given the increasing number of Arab countries or regimes that are normalizing relations with this state of immigrants. Such attempts to normalize relations with Israel disregard historic Palestine and the Right of Repatriation of Palestinian refugees; it disregards the fact that Zionists are colonialists and that Israel is a colonialist settler occupation. While normalization serves to legitimize Israel's existence - making it de jure memorialization and the visual reconstruction of historic Palestine and the Nakba serve to delegitimize such de facto existence.

This study is hence timely as it serves to demonstrate how visually represented leitmotivs of the Palestine Question are employed as powerful evocative tools and "visual stories" for the assimilation of individuals into an uprooted community - not an imagined community - and hence the memorialization and reconstruction of historic Palestine, i.e., pre-1948 Palestine. Such visual stories can become emotive symbols for national themes and their memorial function, and so can act as a rallying cry against normalization and a mobilizing tool for resistance and renaissance.

\section{Literature Review}

\subsection{Visual discourse and the nation}

Visual representations are significant means in the construction of the nation. Amer (2018) holds that in the case of "national liberation movements, images become cultural tools for communicating nationalist ideas and mobilizing the 
nation behind a national cause" (3). They act as a form of "counter-hegemonic discourse by portraying daily reality and suffering" (ibid.), demystifying events and memorializing/reconstructing them.

Visual representations or "representational iconic images," as shown in this study, manifest realism, vividness and stark emotiveness, which act to emotionally involve the viewer and elicit "intense emotional responses" (Cross 2006). Images which become national symbols are thus significant as they become interpretive cognitive frameworks. They drive national struggle for liberation of territory, independence and self-determination.

Therefore, visual representations of the nation whether real or imagined constitute a significant part of nationalist discourses and nationalist imagery. The purposes of such representations, according to Baron (1997) are obvious "Images of the nation are meant to reaffirm the unity of the nation and give the concept of nationhood greater immediacy" (105).

As such, visual representations of a nation constitute a major weapon in the struggle for national liberation. They help mobilize the people behind a nationalist goal and shape their collective identity. "Their influence is deemed powerful as they contribute to the formation of ideologically-based political and cognitive models of the national "in-group" and in solidifying a national narrative that continues to be enacted [and invoked], especially in times of crisis and war" (Amer 2018:2). They also have "socio-cognitive functions in that they underlie a process of shaping collective consciousness and reconstructing the collective experience of uprooting and displacement" (ibid. p. 21).

In addition, images can transmit "the idea of nationalism beyond literate circles" (Baron 1997:122) and so ensuring the involvement of a larger audience, appealing and reaching out to the literate as well as the illiterate; and so they could be more powerful or effective than verbal signs. Nationalist iconography (Baron 1997) is, therefore, instrumental in the construction of a coherent collective, and so national identity and the process of national self-determination.

\subsection{Palestine in visual discourse}

Since its de facto creation, Israelis have persistently endeavoured to efface Palestine from the global public memory. They have discursively and nondiscursively attempted to erase the physical geography and human demography of Palestine, creating through various methods of ethnic cleansing a metamorphosis of historic/mandatory Palestine.

This new reality or the wiping of Palestine off the map and the constant and systematic attempts of the newly-found state "to delete the Palestinian presence in Palestine" (Walsh 2009: 24) has resulted in the emergence of certain predominant Palestinian national themes. Thus "Palestinian nationalism is driven by the intimate intertwining of the present reality and experiences of dispossession, dispersion and statelessness of most Palestinians since Israel's creation in 1948" on their soil (Amer 2020: 6).

Such nostalgic national themes encoded verbally (verbal semiosis), visually (visual semiosis) and sometimes multimodally or intersemiotically (verbal-visual 
intersemiosis) (Economou 2009) with other semiotic signs or systems of signification - first by Palestinian and Arab nationalist artists, and then by international sign makers - are central to the Palestinian national narrative, identity or national self-identification and future aspirations and resolve for return. Such national themes, visually and in many cases multi-modally represented, have become (part-for-whole) metonyms and then symbols of the Nakba, serving to perpetuate in the collective Palestinian consciousness and the world memories of loss and dispossession, the Right of Return, and resistance and steadfastness, amongst others.

Over the years, the construction of visuals that represent various facets of the Palestine Question has doubled, leading to a rich repertoire of iconography of the Nakba. This plethora in visual representations, however, has not been accompanied by a proliferation of visual studies that systematically analyze such iconography. While there has been a huge corpus of studies that analyze verbal discourse on the Palestine Question, studies that analyze visual discourse remain skimpy and patchy.

As for the particular theme of national reconstruction, though there have been some studies on some aspects of the visual representation of the Israel/Palestine Question in general (e.g. Amer 2018; Abu Hatoum 2016; Ramamurthy 2016; Alloul 2016; Abu Hashhash 2006; Bartelt 1998), this topic, in particular, has remained unresearched as there are no studies that deal with visual representations and the reconstruction of historic Palestine. A look at the literature can quickly reveal such dearth in visual studies pertaining to this topic. This dearth in visual studies on the role of visual discourse in the reconstruction of the Nakba or the ethnic cleansing of Palestine - the role of visual representation in reconstructing the Palestine Question as the plight of a people who have been driven out of their homeland — provided the impetus for the present study.

\subsection{Historical background: Genesis of the Palestinian Nakba}

In the aftermath of the First World War, "Palestine came under the British occupation" (Farrah and Halahlah 2020: 204) and remained under British domination until 1948. In May 1948, the State of Israel, a country of immigrants, was founded, in the heart of Mandatory Palestine (1917-1948), as envisaged and initiated by the carefully worded Balfour Declaration (1917) — the foundational stone for modern-day Israel. This was Britain's pledge of "a national home for the Jewish people" in Palestine. This pledge or hegemonic act — the ultimate establishment of a Jewish State in Mandate Palestine as contemplated by the British Crown - took place following militarized Zionist immigrants' constructed later as 'Israel Defense Forces' - launch of a premeditated campaign to drive out the native population of Palestine from their homeland - a crime of ethnic cleansing (Pappe 2006) that has led to the mass expulsion of the Palestinians form their villages and the onset of their ongoing dispossession and suffering. "From close to one million Palestinians only around 150,000 remained in the newly created state. From 500 villages, only 100 remained undestroyed by 
the Zionist Israeli troops, and all major cities were emptied of most of their Palestinian residents" (Shihade 2012: 109).

This robbing of the Palestinian people of their homeland and the sociocide and politicide of Palestine as a nation and as a state, perpetrated through ZionistBritish cooperation (Gutwein 2016) as envisioned in 1917 by the British government, and then the systematic memoricide by the new settler state of such genocide - referred to by Palestinians and Arabs as The Nakba (of 1948), constitute, along with the 1967 Israeli occupation of the rest of historic Palestine and the resultant displacement and dispossession of many more Palestinians, what in essence, the Palestine Question is all about, and underlie much of the ensuing spillover of regional wars and political unrest in the Middle East and probably the world at large.

\subsection{Theoretical background: Visual discourse and the representation of reality}

A major semiotic development in the early $20^{\text {th }}$ century was the "linguistic turn"

- the recognition that language is not a neutral means for the transmission and communication of knowledge but rather a constructor and shaper of knowledge where power is knowledge and knowledge is power (Foucault 1976; quoted in Clarke 2005). This realization about the role representation plays in the perception and construction of knowledge has led since the early 1990s to what has come to be known as the "critical turn" - the realization or zeitgeist consciousness that language can be employed for purposes other than those of the telementation of ideas from the mind of one individual to another - to that of action, power and social control. This is the realization that social realities are linguistically/discursively constructed, and that discourse reproduces society as well as being reproduced by it (Titscher, Meyer, Wodak and Vetter 2000; Fairclough 2001; van Dijk 2008; Young 2009; Wodak and Meyer 2009, Krzyżanowski 2016, etc.). Yet, a third significant turn in the semiotic landscape (Kress and van Leeuwen 2006) arrived especially at the beginning of the $21^{\text {st }}$ century - the "visual turn" (Jay 2002).

This is the realization that communication is rarely monomodal and that, for example, a mode such as writing, "often conceptualized and analysed as if monomodal, has, in fact, a visual and material presence, and that the meaning of 'writing' cannot be separated from such factors" (Ravelli, Adami, Boeriis, Veloso and Wildfeuer 2018:398). This realization has drawn attention, as Kress and van Leeuwen (2006) state, to "the inherent multimodality of all communication."

This multimodality has become more obvious and been made highly possible by "digital technologies" (Ravelli et al., 2018), by the "technology of visualization" (Campbell 2012), of "visual and multimodal phenomena," of "visual and multimodal communication," where the visual has become a "fundamental aspect of communication" (Ravelli et al, 2018: 399).

Indeed, the role of the visual in our social and political world has become more complex and more significant. Texts nowadays "are becoming increasingly multimodal - they communicate to us through graphics, pictures, layout 
techniques as well through words" (Thuy 2017:164). In the words of Kress and van Leeuwen (2006), "representation is always multiple." This is a "rapidly growing realization" (ibid).Visual communication is then a hallmark of technologically-driven modern literacy where visual symbols are increasingly intertwined intersemiotically with verbal symbols and other complexities that go far beyond traditional definitions of literacy.

Now like linguistic structures, visual/multimodal structures point to particular interpretations of experience and [enact] forms of social (inter)action. Visual elements are thus ideological. In the words of Kress and van Leeuwen (2006):

Visual structures do not simply reproduce the structures of 'reality'. On the contrary, they produce images of reality which are bound up with the interests of the social institutions within which the images are produced, circulated and read. They are ideological (p.47).

Thus visual discourse is equally ideologically biased and politically motivated. The presence of images or other visual signs in a piece of discourse is thus not an embellishment. It is subjective and intricately linked to the image maker's personal, political and ideological interest and affiliation. They are meant to either reproduce the status quo or resist it.

Therefore, Kress and van Leeuwen (2006) observe that visual representation is motivated by the sign maker's interest, and so always partial. It serves particular cognitive purposes. It allows producers to encode in the visual mode their "mental picture of reality and how they account for their experience of the world" (Simpson 1993: 89). They are, according to Kress and van Leeuwen (ibid.) a "means - always — for the articulation of ideological positions"(14).

\section{Methods: Social semiotic analysis}

Following Halliday's functional socio-semiotic theory of language (1975, 1978, 1994, 2004), Kress and van Leeuwen (2006) propose that visual texts, like language, are "resources for encoding interpretations of experience and [enacting] forms of social (inter)action," (p.1); and so similarly serve, as a semiotic mode of communication, three functions or levels of meaning where "three strands of grammar operate simultaneously:" representation, interaction, and composition - synonymous with Halliday's ideational, interpersonal, and textual metafunctions, respectively. In light of this "social semiotic, metafunctional view of communication" (Royce 1998: 25) as expressed by Halliday in his Systemic Functional Grammar (SFG) model, Kress and van Leeuwen (1990, 1996, 2006) have developed a tripartite "grammar of visual design" for "reading" or interpreting these three layers or types of meaning interwoven in a visual text: representational meaning, interactional meaning, and compositional meaning. Below is a concise but pithy description of each of these meanings or three accounts of the visual system of representation.

First, the representational meaning (ideational metafunction) deals with who or what is in the visual frame (represented participants, whether animate or 
inanimate, and interactive participants); and what action is taking place; and where, who with and by what means. The representational meaning of a visual text deals with patterns of representation. This can be either narrative patterns or conceptual patterns. Narrative patterns or representations create (through represented participants and actional vectors that indicate action) social action, and so serve to "present unfolding actions, processes of change, transitory spatial arrangements (Kress \& van Leeuwen 2006:59)." These are categorized into a set of four transactional structures described by Kress \& van Leeuwen (ibid.) as narrative processes. These are (1) action processes; (2) reactional processes; (3) speech processes and mental processes; and (4) conversion processes. On the other hand, conceptual patterns/representations, design social constructs; they represent participants "in terms of their class, structure or meaning, in other words, in terms of their generalized and more or less stable and timeless essence" (ibid.). Like narrative patterns, they are also categorized into a set of (three) transactional structures or processes: (1) classificational (where participants are related to each other "in terms of a 'kind of' relation, a taxonomy"), (2) analytical (where participants are related to each other "in terms of a part-whole structure" Carrier vs. Possessive Attributes) and (3) symbolical (where "processes are about what a participant means or is" - Carrier vs. Symbolic Attributes) (ibid., Chapter $3)$.

It should be stated here that unlike visuals of conceptual representation, the hallmark of visuals of narrative representation is "the presence of a vector: narrative structures always have one, conceptual structures never do" (Kress \& van Leeuwen 2006:59). "In pictures, these vectors are formed by depicted elements that form an oblique line, often a quite strong, diagonal line" (ibid.). It is equally important to state here that "the categories of visual grammar do not have clear-cut edges, and specific representations can merge two or more structures for instance, the narrative and the analytical" or the narrative and the symbolical (ibid. p. 95). And so like language, images can embed more than one structure or process - an embedding process - in their visual syntax, resulting in complex structures where minor processes are embedded in major processes.

Second, the interactional meaning (interpersonal metafunction) of an image text deals with patterns of interaction or in the words of Kress and van Leeuwen (2006) "with the things we can do to, or for, each other with visual communication, and with the relations between the makers and viewers of visual 'texts' which this entails" (p.15). In other words, the interactive meaning deals with two kinds of participants - represented participants and interactive participants - that images (and other visual genres) involve, and the relations between them. Represented participants are "the people, the places and things depicted in images." Interactive participants, on the other hand, are the real "people who communicate with each other through images, the producers and viewers of images" (p. 114).

Kress and van Leeuwen (2006) propose three ways or interactional "simultaneous systems" to examine the interactive meanings of images - how relations between represented and interactive participants are visually formed. 
These are (1) the visual system of gaze or contact (demand or offer); (2) the visual system of size of frame or social distance (intimate/personal, social, or impersonal), realized respectively in close-up, medium or long shots of represented participants; and (3) the visual system of point of view or attitude which refers to the camera angles used in an image - the horizontal angle and involvement, and the vertical angle and power (Chapter 4). And so the visual "systems of 'image act', 'social distance' and 'attitude"" (Kress and van Leeuwen 2006:152) as realized in the "direction of the look, the gaze of represented participant, the size of frame, and the viewing angle all play important roles in identifying the relation between the represented participants and the interactive participants" (Thuy 2017:166).

Third, the compositional meaning (textual metafunction) of an image deals with the visual features that make a visual text — complexes of signs — "cohere both internally with each other and externally with the context in and for which they were produced" (Kress \& van Leeuwen 2006: 43), thus bringing together representational and interactional meanings. An examination of these features or resources of visual structuring - involves an "examination of those features of the layout or composition of the spatially integrated text which allow the elements on the page to be viewed as coherent parts of the one composite text" (Royce 1998:41). Such examination, according to Kress and van Leeuwen (2006), can be built through three interrelated visual systems of composition: (1) information value (the intra-visual placement of pictorial elements in the various 'zones' of the image: left and right, top and bottom, centre and margin), (2) salience or visual weight (perspective or foregrounding vs. backgrounding, relative sizing, contrasts in colours, differences in sharpness of focus, placement of elements in the visual field, cultural symbols, etc.); and (3) framing (or its absence), signifying and stressing "group identity," or "individuality and differentiation" (ibid. p. 203). Thus, "these compositional aspects are basically concerned with where the visuals are placed spatially on the page...the relative size of the visual... and how the visuals interact with each other" (Royce 1998).

This study employs this now established framework for the analysis of a number of salient images and posters that are used as metonyms and symbols for the Nakba or the ethnic cleansing of Palestine.

\section{Data collection: Memorialisation of the Nakba}

To this end, and in light of this model — descriptive analytical framework — of three accounts for "reading"/interpreting "visual texts" or visual discourse where images are viewed and treated as socially-situated, politically-motivated and visually-constituted, "structured messages, amenable to constituent analysis" (Kress and van Leeuwen 2006: 24) — this study sought to analyze such systems of visual design encoded in six popular iconic Palestinian visual representations/images. These are conventional metonyms that have become symbols of the Nakba. Hence the selection of these images/posters, in particular, was justified by their symbolic and metonymic nature, on the one hand, and the 
centrality of the themes - key/predominant Palestinian national themes - they represent to the Israel/Palestine problem, on the other.

This visual data was taken from the The Palestine Poster Project Archives website $^{1}$. The researcher was not interested in the representativeness of those visual texts, for this is simply unfeasible given the huge corpus of images, but rather in seeing their iconological significance and the socio-political role they play - as a socially-constructed mode of discourse - in memorializing and reconstructing important national themes such as the ethnic cleansing of Palestine and amplifying discourse about it. The reason why the researcher collected such visual "data" from these Archives is the encyclopaedic nature and international character of the Archives.

Three out of the six images selected are produced by Palestinian artists, while the other three are by international ones, hence creating a balance of views. While one image is entirely composed of visual syntax, the other are multimodal. They have verbal elements in them. Different languages - Arabic, English, French - are used in the accompanying verbal texts. This emphasizes, as noted in section, 2 "the inherent multimodality of all communication" and that monomodal communication is rare.

\section{Data analysis and findings}

The study employed Kress and van Leeuwen's model or framework for visual analysisbecause it can be effectively used as a tool for breaking down images into "observable tiny pieces to comprehend their meanings" (Thuy 2017:167). The study sought to analyze and describe the structures of visual "data" selected to realize the kinds of meanings they communicate and how. Some of the images selected aremultimodal representations - images that embody other semiotic elements such as verbal signs. Those other elements or semiotic signs were also analyzed.

\subsection{Handala: Icon of homelessness, injustice, and steadfastness}

Handala - a cartoon (a genre within the visual semiotic mode) by the Palestinian artist/cartoonist Naji Al-Ali (1937-1987) of a ten-year-old barefooted, raggedlydressed homeless Palestinian refugee camp child - is an icon of resistance and a symbol of homelessness and injustice.

As seen in figure 1 below - an image produced in 2018 by the French artist/designer, David Abry, in France - Handala has become a national symbol, metonymically representing the indigenous Palestinian people as "a community of victims;" immortalizing their bitter sense and experience of Nakba; and epitomizing their national consciousness, struggle for self-determination; and rejection of normalization and solutions designed the "American" way.

"Born" in 1937, i.e., the Palestinian cartoonist's year of birth, Handalawas ten years of age when Zionists/Israelisperpetratedthe ethnic cleansing of his homeland, i.e., 1948. His age froze at that point in time. Hehas always been ten years of age and will always be ten until he returns to his homeland in which he 
and his fathers and forefathers were born generation after another; only then will he begin to grow up like normal children.

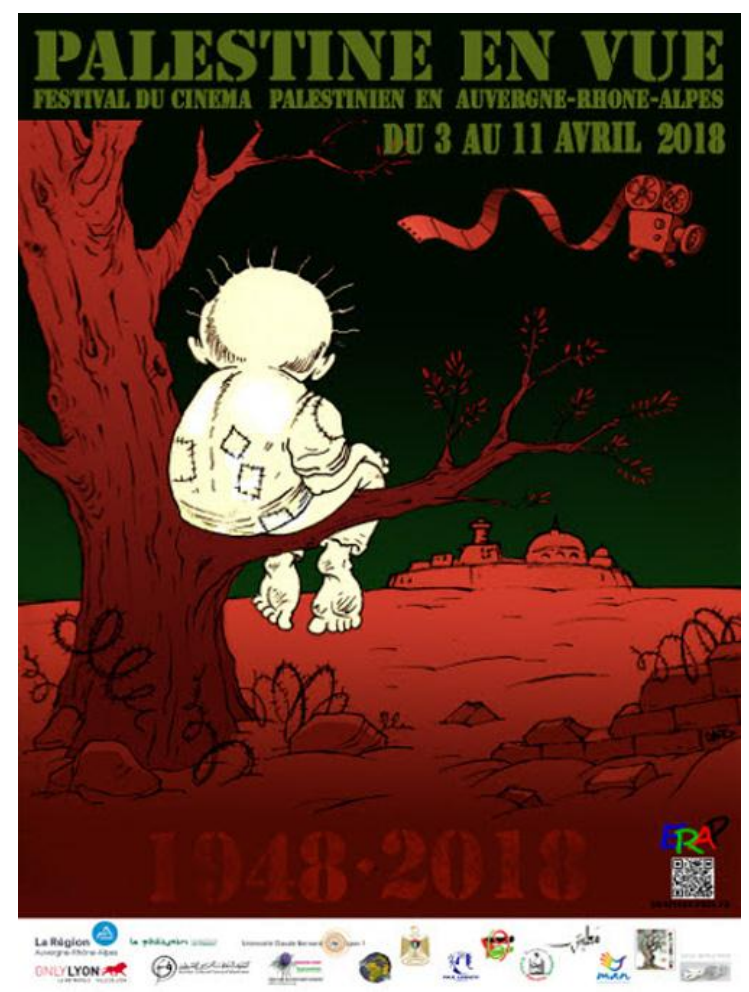

Figure 1. Palestine enVue - 4 (Palestine in View)

A conceptual representation encoding a symbolic process, this image is an icon of the Nakba. The image does not depict action, hence is the symbolism of the image. The representational meaning of this visual of conceptual structure is embodied iconographically in Handala, the only human represented participant in the image. The image embeds a reaction process; of looking at the buildings in the distance - realized by an invisible eyeline vector. Feeling distressed at the conditions of exile, poverty as a refugee living in a refugee camp, Handala has decidedto take this posture - turn his back as long as his homeland is settled and marauded by foreigners.

He has adopted this posture as a reaction to the existential crisis and as a sign of his rejection of solutions designed the "American" way. He is a refugee; he leads a threadbare existence as is the case of children living in refugee camps. This inexorable rejectionist attitude, symbolized by Handala's turning back (and in many other depictions, in his clasped hands behind his back) makes the dream of return the focus and the raison d'être of the Palestinian refugee - not a 
mere quixotic image that tantalizes one's imagination. He is steadfast and he is willing to sacrifice his life and all that he has for the sake of Palestine and his return to it. He is willing to forsake the world for Palestine. There is no intimacy here. He is unwilling to talk or negotiate. He is haunted by memories of a wartime childhood - as could be construed from the secondary participant, the unrolling film reel - a circumstance of accompaniment as would be described in the grammar of visual design. He seems to be locked in a silent nostalgic communion with his "stolen" homelandwhich though visible from afar, he cannot or is not allowed to enjoy its warmth and protection.

This is further intersemiotically expressed by the verbal heading Palestine in View, which makes viewers see Handala as Palestine and see Palestine through Handala. He rejects to succumb to this bitter reality. He wants dignity which can only be achieved by returning to his homeland - the only salvation for the existential crises of the Palestinian people. But as the actor is a child who is obviously poor, we as viewers cannot help but be drawn vicariously to him and the conditions that have made him adopt this sombre, 'defying' posture.

In the visual frame we also find other represented participants - the inanimate old trunk of a tree on which Handala is perched, the barbed wire, the bare landscape, and the buildings in the distance. These are highly symbolic. The trunk, for example, represents through a symbolic process Palestinian rootedness and primordial organic attachment to the land. Handala, perched this way in front of his denied homeland, conjures up the poignant image of homelessness. The barbed wire surrounding a distant Jerusalem - a metonym for historic Palestine - emphasizes its status as a dream.

From the point of view of the interactive meaning, the image, given the complete absence of gaze, is an 'offer' picture. It is a visual 'offer' rather than a 'demand'. The participant is visually offering us information. Such information, however, invites - rather than demands - the viewer of the visualto sympathize with him and probably indirectly dig into his life to find out about the causes behind this asocial aloof stance. In terms of the other interactive systems, this is afrontal, low-angle,full shot image, empowering the powerless, and allowing for a greater view of the represented participant. The full shot allows Handala to be viewed from head to toe - his clothes or absence of clothes, his innocence, his position, etc. The interactive participants, given the absence of gaze or eye contact, are made to wonder why he is turning his back. This questioning leads to the tragedy he and his nation are living - the conditions of exile and homelessness as the result of the ethnic cleaning of Palestine. But despite this absence of gaze, the image, being frontal - though with a back view engenders involvement with the represented participant. It makes what we see, willy-nilly, part of our world — not someone else's.

The ambivalent back view triggers by virtue of being frontal deep attachment. But this is mixed with a desire to distance himself from the world which he views as unjust; and will remain turning his back so long as he continues to be denied the Right of Return to his homeland. "But to expose one's back to someone," Kress and van Leeuwen (2006) observe "is also to make oneself 
vulnerable," and so despite this apparent indifference and aloofness this posture signifies, the fact is that this is an abandoned child that the world has forsaken. And sothe apparent aloofness caused by the back view is not only being offset by the frontal shot which creates attachment but also by the conditions of deracination the represented participant has undergone and the sense of bitter injustice he is feeling; and with which the interactive participants are drawn accordingly to experience and feel.

This harsh reality is accentuated in the compositional structures of the visual text - how the representational and interactional elements are arrayed or woven together in the visual text so as to make a coherent image. This is first realized first in the position of Handala being foregrounded (what is given or known to us) vis-à-vis the buildings in the background as the focus of his gaze (the new). This is validated by the left/right balance of the image, and also by the (broken) wall in line with the tree, which suggests a kind of before/after or here/there relation. Being foregrounded is a primary position in terms of information value. Second in the visual salience of Handala again being foregrounded and the fact that he is a potent cultural symbol, which makes him not only conspicuous but also of a high visual weight - the first visual element to be noticed; and third in the monochrome image of Handala, which, given the colour saturation of the rest of the elements in the visual field, further accentuates the salience of the represented participant - a metonym for the Nakba/the Palestinian diaspora.

Furthermore, given the amount of light or illumination Handala receives, he is being, comparatively, in sharper focus. Such focus and centrality in terms of information valuation (central placement) and visual salience (prominent size, foregrounding and sharpness of focus) perceptually draws, if not forces, the viewer into the world or harsh reality of the represented participant - the most important or stressed 'item of information' in the whole, "the Big Idea of the story" (White 1982:127; cited in Royce 1998: 43) - Handala/Palestine or the Palestine Question.

The harsh reality of the ethnic cleansing of Palestine and the ensuing homelessness of the Palestinian people are further reflected in the monochrome image of Handala, being mere black and white, which accentuates, along with the cold bareness of his feet, the stark harshness of homelessness or statelessness - as opposed to the warmth of the "homeland." It is a concentration camp just like a prison camp, no fun, no Ferris Wheels, no fairy lights, no charismas, no Santa Claus, no parks - nothing but tattered clothes, and a heavy heart. The black and white induce some sort of sobering realism.

There is further compositional structuring in the image, as far as framingthe third key element in composition - is concerned. The poster can be viewed as a vertical triptych: ideal: the words on the top, expressing the promise of tomorrow; centre: the image mediating the ideal and real; and real: the dates at the bottom, representing the status quo, the ongoing harsh and bitter reality of homelessness/statelessness/diaspora/occupation/apartheid - 1948 until the present day. 
A portrait of atrocity, Handala's ragged clothes, hedgehog-like hair and barefeetall serve as a reminder of Palestinian dispossession, underscoring the horrible conditions of refugee camps, and the wrench at being driven out of one's homeland. However, this austere image with the thorny hair he uses as a weapon is meant at the same time to reflect steadfastness and resistance.

Further, Handala's name is suggestive of bitterness in Arabic. This bitterness - a consequence of injustice - is a daily reality lived by millions of homesick Palestinian refugees cantonized in squalid poor camps; and so metonymically, Handala represents the experience of millions of downtrodden refugeesmade to languish in diaspora. Nevertheless, despite this bleak reality and the absence of justice, Handala is unwilling to normalize with colonizers as represented by his rejectionist attitude.

5.2 The tent, the tree, the key, and the Stone: Symbols of Nakba, survivability, resistance and tenacity for return

\subsubsection{The tent and the tree}

Acrimonious recollections of the depopulation and mass expulsion of the Palestinian people from their homeland at the hands of the Zionist gangs of the Hagana, Stern Gangs, and Irgun — predecessor of Israel 'Defence' Forces - to create a "national home" for the immigrant Zionist Jews (Assaiqeli 2013) are oftentimes represented in Palestinian literature and imagery in the form of the tent and the key. A central theme in the Palestinian struggle for national liberation and self-determination is then return and the Right of Return. There is a plethora of images representing this major national leitmotif. It is actually the core of the Palestine Question-the question of "a homeland denied." Figure 2 below represents this 1948 event - a date etched on the collective memory of the natives of Palestine.

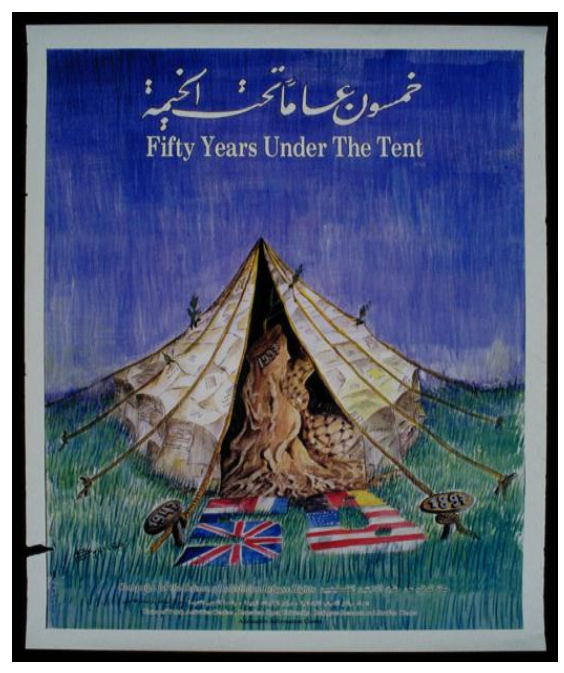

Figure 2. Fifty Years under the Tent 
A conceptual representation encodinga symbolic process, this image is iconic when it comes to the Palestine Question and what happened in 1948. Constructed in 1997 by the Palestinian artist/designer Adnan Al Zubaidy (19512007), the image - a "visual gestalt" of the Nakba — first reconstructs the atrocity of the ethnic cleansing of Palestine - the expulsion of "around a million people" (Pappe 2006) from their homeland or the areas that became the state of Israel, which is in terms of the representational meaning communicated symbolically through the tattered tent and stump of an olive tree. The image let the ethnic cleansing of Palestine continue to reverberate through ongoing Palestinian generations. Second, the image represents the rootedness of Palestine in the Palestinian consciousness and the relentless perennial resolve to return as communicated by the young shoots victoriously forcing their way through the old tent. Third, the image represents a long Palestinian cultural connection with the land of Palestine as communicated by the embrace between the keffiyah - a symbol of Palestinian cultural costume - and the deep-rooted stump. Fourth, it also pictures the perpetrators responsible for the ethnic cleansing. In terms of the representational meaning, this is communicated through the flags of each of France, Germany, the UK, and the USA found in the form of a mat in front of the entrance to the tent. Fifth, the image marks two milestone dates significant inthe evolution and history of "political Zionism" or the settler Zionist enterprise in Palestine: "1897" as the year ofHerzl's proposed "scheme" of a Jewish state in Palestinewhich also significantly points to the recent history or origination of Zionism as opposed to the Zionist claims of long historical connection, and " 1947 " as the year of the UN Partition Plan or UN Resolution 181. This is communicated through the dates engraved on the stakes in front ofthe tent's entrance on the right and the left. A third date engraved in the bark at the top of the stump - 1997 — marks 50 years, i.e., 1947-1997 of dispossession and suffering.

In terms of the representational element, there are no animate participants as such in the image. All represented participants are non-human. Human agency, however, is metonymically and metaphorically represented — using a symbolic process - through inanimate represented participants such as the stump of a tree, the tent, flags, etc. Thus, the deep-rooted stump of the olive tree is symbolic of the Palestinian people and their deep-rooted presence and ongoing perennial attachment to the land of Palestine as opposed to the recent history of Zionism as noted. Since there is no physical activity, then in terms of processes, these meanings are then communicated existentially/symbolically, which is also applicable to figure 3 below.

Significantly, the image draws the viewer's attention to two things: the origin of the Palestine Question, and the steadfastness in the face of such national distress as revealed in the still alive stump, and the new sprouts and branches sprouting out of the tent, making the dream of return an inevitable destiny as one generation passes on the keys to the next until the Right of Return is fulfilled and return to the homeland is achieved. Interestingly, this theme is also communicated 
and reinforced visually in the year 50 being carved in the doormat in front of the tent.

The orthographic text (Royce 1998:42) — Fifty Years Under The Tent crafted in Arabic and English accentuates "intersemiotically" the suffering engendered by the Nakba. Here the visual message elements are being translated or ratified verbally; they are being reinforced intersemiotically through a collocational sense relationby the verbal text, resulting in what Royce (1988) calls "an intersemiotically consistent and coherent message."

In terms of the interactional meaning, the image is a full shotof a tent - a token of the Nakba. Other represented participants are also the stump of a tree and four flags. This full view makes the scene quite visible and memorable. In terms of the horizontal angle, this is a frontal shot designed to maximize involvement of the viewer. As for the vertical camera angle, this is an eye-level angle, which coupled with the frontal point of view encoded in the horizontal angle, is meant to involve rather than detach the interactive participants (viewers and the image producer). It is meant to set the stage for a discourse on the origins of the Palestine Question. Framed as such, the shot imparts the tent with power that withstands the ravages of time and passage of years - a token of Palestinian creative suffering and survivability; and a memorial against the forgetfulness of history and distortion of facts.

In terms of the compositional meaning, the bright and vivid colours, the central position of the stump of tree, representing the geographic aspect of Palestine, and the nature of the symbols represented - the stump of a tree, the tent - being potent cultural symbolsall intensify the themes communicated in the image.

\subsubsection{The key}

As shown in figure 3 below, the key has emerged since the first days of the Palestinian mass expulsion and dispossession. It has emerged as a main "witness" that those refugees had their homes in idyllic pre-1948 Palestine. Though most of their actual homes have been erased through a Zionist process of "renaming"and "green-washing" of Palestine's originallandscape, they havenever left their keys, which have become a symbol of their expulsion and a goal of their return and the Right of Return, no matter how long it may take, for they - the keys being a symbol and a witness - are being transmitted by the fathers or ancestors to the descendants, generation after another, defying the passage of time and Israel's systematic pursuit of Palestinian memoricide. 


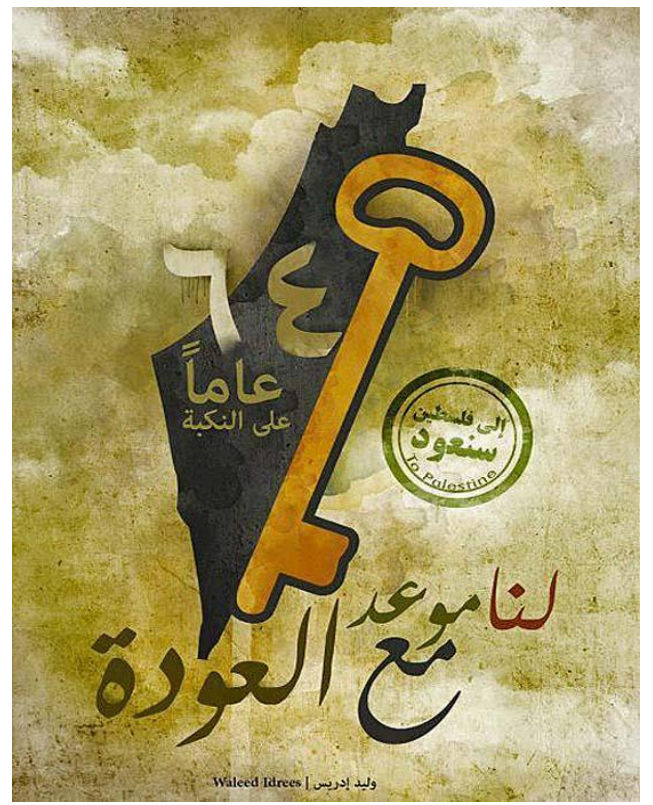

Figure 3. We Have an Appointment with Return

Produced by the Palestinian artist/designer Waleed Idrees in 2012 and published in Palestine, this image commemorates - as seen in the accompanying or intersemiotic verbal text in Arabic - the $64^{\text {th }}$ Anniversary of the ethnic cleansing of Palestine - the Nakba.

A conceptual representation encoding a symbolic process, this conceptual visual is another conventional metonym that has become a symbol of the Nakba. In terms of the representational meaning, no human represented participants are there in the visual frame. However, just as in figure 2 above, human agency is visually realized in the key, the key here being a symbol of the Palestinian people - the de jure or rightful owners of the land - and their plight. It is only a key, one key, but it metonymically symbolizes the plight of the Palestinian people - the Palestinian refugees, their man-made Nakba, and their tenacity for return despite the passage of years. The key has been and will ever be inherited as an heirloom and passed on down from generation to another, defying oblivion, serving as a constant reminder of the home that once was "ours" and to which "we" shall return as translated or ratified intersemiotically through a collocational relationship by the Arabic orthographic texts: We Have an Appointment with Return, and To Palestine we shall return. This multimodal message is an "intersemiotic presentation of certainty" that makes the end of the colonialist Apartheid regime in Palestine and return of the Palestinian people to their denied homeland a promise divine.

In terms of the interactive resources of the visual, this is a frontal (horizontal angle) eye-level (vertical angle) full shot image meant for complete visibility, symbolically linking the key with the homeland. The long shot of the 
key is being foregrounded against the map of historic Palestine, thus bringing alive a history of 64 years as verbally represented -64 years since the ethnic cleansing of Palestine - of diaspora, with the goal of returning being a matter of time. The frontal angle draws the interactive participants to the world of the represented participants, almost letting them share the same world. The image is not meant as an object for dispassionate reflection or contemplation. Rather the message communicated is: 'what I see is part of my world; it concerns me.'

In terms of the compositional elements, the map of Palestine and the Key are placed in the centre of the image, a position that accords to such represented participants a high information value. Such valuation is being further enhanced by the big size of the foregrounded saturated key which is made to encompass the whole of historic Palestine and not just part of it. Further, framing the key this way alongside historic Palestine signals a highly significant message that Palestine - the whole of Mandate Palestine and not just the territories occupied in 1967 for example - is an indivisible whole, not subject to partitions or twostate 'solutions.'

The same national themes or visual symbols symbolizing the Nakba, rootedness and organic perennial connection with the land, survivability, and tenacity for return can also be seen in figure 4 .

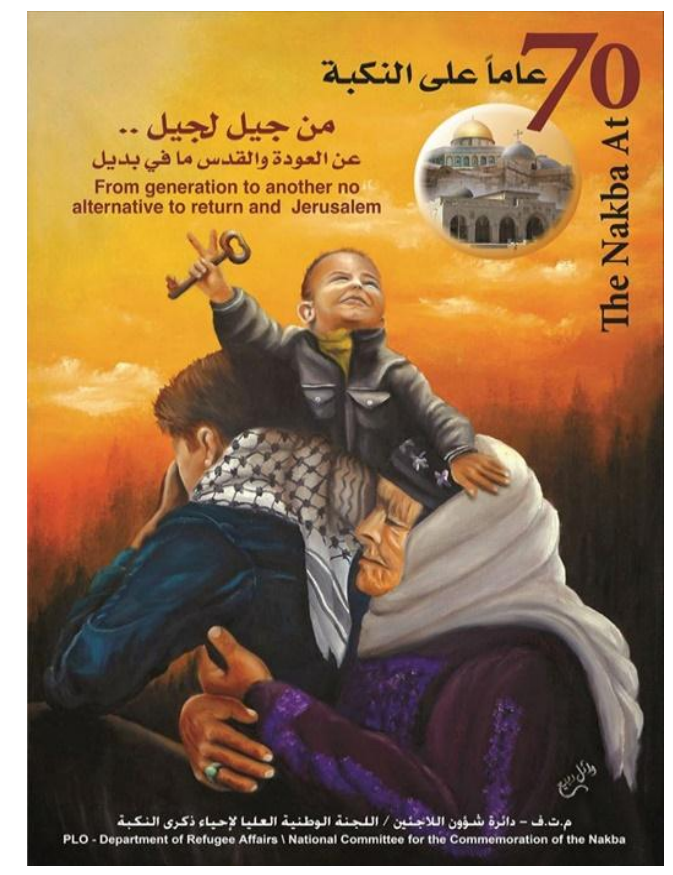

Figure 4. The Nakba at 70 
Gravid with connotative meanings carried out largely through symbolic attributes (e.g. the key as being passed down from a generation to another, the $\mathrm{V}$ sign, the keffiyah, the deeply-rooted tree-shape of the represented participants, etc.) the image - a "visual gestalt" of the ethnic cleansing of Palestine emphasizes the age-long rootedness of the Palestinian family roots in the land of Palestine. The old grandmother, and her son and grandson all spring from the same soil to which they are perennially and genetically attached and determined to return despite the via dolorosa that the Palestinian people have to take in their course for return as represented in the woman's wrinkled face and distressed closed eyes.

Produced by the Palestinian artist/designer Wael Rabei in 2018 and published in Palestine, this composite text commemorates — as seen in the accompanying intersemiotic verbal caption in Arabic and English - the $70^{\text {th }}$ Anniversary of the Nakba.

A conceptual representation encoding a symbolic process, this image is another conventional visual representation of the Nakba.The representational meaning here is made visually through an extended Palestinian family represented as the trunk of a tree, firmly rooted in the land like an olive tree, with their offspring sprouting and rising like a phoenix risen from the ashes of Palestine with the V sign, holding the key — the symbol of and "witness" tothe Nakba and the Right of Return.

Represented or framed this way, the image underscores the organic inseparability or social cohesion of the Palestinian society across generations. The imagethus also represents survivability and the tenacity for return represented in the key being passed down from the Nakba generation to their descendants. The visually salient key - a circumstance of means - here becomes the hope, the straw at which the drowning clutches, the elixir of life, and so theraison d'être of the Palestinian; it is the witness to the Nakba - it is the key to his/her"Paradise Lost."

The cultural national costumes worn by the old woman and the keffiyah by her son accentuate the Palestinian depth and primordial attachment to the land. These visual message elements are being also reinforced multimodally in the intersemiotic verbal texts: From generation to another, no alternative to return and Jerusalem, andThe Nakba at 70.

This brings the extreme long, low-angle shot of Jerusalem - a secondary participant analyzed as a circumstance of accompaniment - into the picture. The extreme long shot indicates the distance that has to be travelled to reach Jerusalem and so this is symbolic of the uphill struggle needed to retrieve or free Jerusalem. But this worm's eye view of Jerusalem fills the viewers with a sense of awe as it accentuates the elevated position of Jerusalem in the hearts of the Palestinians on the one hand, and the mystical or spiritual power it has over them, on the other hand. This elevated grand position, realized interactionally by a low-angle shot as noted, grants Jerusalem the grandeur and splendour it deserves, thus making it a focal point for the aspirations of the Palestinians. 
The image is profound and highly symbolic. In terms of the interactional meaning, the image is a medium close-up as far as the social distance or subject size is concerned. Framed this way, it lets the represented participants' emotions dominate the scene, engendering a strong attachment and a kind of strong personal engagement and involvement with interactive participants. The interactive participants are drawn into the world of the represented participants. This narrows the social distance between the represented participants and the viewer(s). In terms of the camera angle, this is a frontal low shot image, lending the represented participants despite their vulnerability — being a child, an old woman and an unarmed young manpower and resolve.

In terms of textuality, the representation of details (as can be seen for example in the wrinkles of the old Nakba survivor's anguished visage - the woman), the saturated, differentiated colours, and the size of the image all accord the image with realism, thus attracting the interactive participant(s) to deeply identify with the themes of this trans-generational atrocity image.Placing Jerusalem with its holy sites at the highly valued top section of the image bespeaks of the kind of significance this holy city means to the Palestinian people in their struggle against exogenous domination.

In terms of visual salience, the fact that the child is made to occupy the top section of the main element of the image - a highly valued section in terms of information value - draws attention to the survivability of the Palestine Question and the tenacity of the Palestinian refugees to return to their denied homeland. If the Nakba generation cannot - due to the current power imbalance - make it, then the younger generations will make it as long as the key is being held on tenaciously and passed down from one generation to another - as revealed and enhanced by this image.

As far as framing is concerned, we get the impression that this visual composition has two sections or spaces weakly separated by the horizon and emphasized by the darker lower space and lighter upper space, where the Nakba survivors and their immediate descendants - the old woebegone woman and her adult son - occupy the lower section, synonymous with the harsh realities of diaspora and exile, and the deep rootedness of the Palestinians to their homeland; and the upper section of the image, occupied by a shot of Jerusalem - a metonym for Palestine - positioned further up in the distant horizon, along with the third offspring or generation of the Nakba - the grandson - a shoot from the womb of suffering,forming a bridge between Nakba survivors and the generations to come. $\mathrm{He}$ is penetrating with the key — the lifebuoy/the elixir of life - the present clouds of darkness into the promise of tomorrow - the inevitable return to free Palestine. The tenuous boundary - there is no sharp demarcation - between the dismal reality atpresent and the promising ideal future in this polarized composition expresses the nearness of this tomorrow. ${ }^{2}$

\subsection{Jerusalem: Symbol of spiritual and historical connection to Palestine}

The spiritual and historical connection with Palestine is epitomized in Jerusalem seat of Al-Aqsa Mosque and Church of the Holy Sepulcher; and so the focal point 
of not only Palestinian Muslims and Christians alike, but also the whole of the Muslim Umma as well as Christendom worldwide.

The position and significance of Jerusalemforthe worldis clearly and strikingly demonstrated in figure 5 below - a conceptual representation encodinga symbolic process. A moving picture, the image represents the centrality of Jerusalem for the Palestinians and free citizens, and consequently the kind of responsibility and onus they have towards its liberation from present colonizers and protection and safety against new invaders.

A cursory look at this image can reveal the significance of Jerusalem to the world at large. The image visually reflects this in such a way that no words can probably be as or more expressive — the epitome of the old adage: "A picture is worth a thousand words."

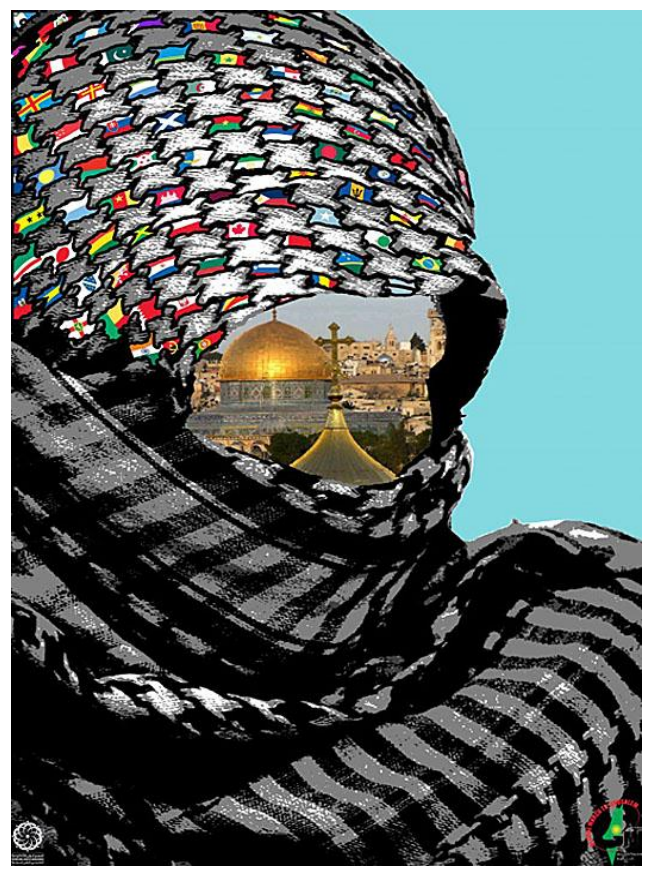

Figure 5. Oh Jerusalem, All the World is Coming to You!

Constructed in 2012 by an international artist/agencywhose identity according to the Archives website is still unknown, and published by Global March to Jerusalem (GMJ), this image makes a loud statement about the position of Jerusalem to the whole world as can be seen in the visual elements of the image (see analysis below) and the accompanying verbal text in English.

From the point of view of representation, the image depicts a patriot or a freedom fighter with his orher face and shoulders except for the eyes wrapped completely in the Palestinian cultural headgear, the keffiyah, with his/her eyes being depicted as Jerusalem. 
The structure/pattern of the image is conceptual, symbolic rather than narrative. The meaning is communicated conceptually through a symbolic process. This works in two ways. On the one hand, holy places of worship such as Al-Aqsa Mosque - the third holiest shrine in the entire Muslim World after those in Mecca and Medina - and the Church of the Holy Sepulchre — scared to Christians - make Jerusalem a city that transcends a specific ethnicity, religion or nationality. They afford or accord Jerusalem the position of an international cosmopolitan metropolis. This global character of Jerusalem is further accentuated in the panoramic view of the world flags, making Jerusalem the cynosure of all eyes rather than those of Jews alone.

On the other hand, the actor'seyes are further being foregrounded by depicting Jerusalem through them. Representing Jerusalem as the eyes and through the eyes of the represented participant is highly symbolic and highly significant.

Placing something or someone in one's eyes signifiesthe epitome of affection and endearment, protection and love. The closest verbalidiomatic expression here would be "the apple of one's eyes." Making someone the apple of your eyes and keeping an eye on someone or something signifies solicitude and concern, custody and responsibility, attachment and attentiveness, support and importance. Thinking of someone or something this way would mean that nothing is dearer or closer. This clearly communicates the level of attachment, the kind of love, and the degree to which a Palestinian, in particular, and a free citizen, in general, is willing to go and sacrifice in defense of Jerusalem - the centre of their spiritual attachment.

The keffiyah has as part of its colourful embroidery the flags of the nations of the world. This makes Jerusalem the cynosure of all eyes and so communicates the centrality of Jerusalem to the entire world.

From the point of view of interactive meaning, this is a tight close shot taken from an oblique angle (horizontal angle) at eye level (vertical angle), thus positioning the represented participant closer to the viewer with no power differences. The oblique angle makes the viewers to view the content of the image in a relatively detached way — in an objective manner. The represented participant's eyes are metaphorically represented as Jerusalem. This underscores the symbolic significance of the object of the gaze. The represented participant is not only eying Jerusalem but also Jerusalem is his/her eyes. Such strong attachmentis also communicated by the frontal rather than oblique point of view of Jerusalem, with its cosmopolitan holy sites. We are therefore automatically drawn to view what the represented participant is viewing; to focus on what he/she is focusing; to share them their emotions and concerns. We are centrally involved with what the represented participant is viewing. This has an effect ofunifying us towards one destination - Jerusalem!

It is important to note while discussing this parameter of the interactive meaning - the gaze — that this is an "offer" picture where the represented participant is seen as an item of information or an object of contemplationand dispassionate reflection for us the viewers/interactive participants to contemplate, 
study and appreciate. This type of gaze applies to all the images that have human represented participants in this study, i.e. figures $1,4,5$, and 6 . It should also be observed here that this type of look or indirect form of address - the offer - is meant, through the sense of disengagement rather than connection it imparts between the represented participants and the viewers, to maximize the objectivity of the images where such images are - like diagrams, maps and charts - to be construed as "offering" information or communicating knowledge in an impersonal, objective, dispassionate manner. Emotive personal involvement of the viewer is signaled, however, by other semiotic systems or subsystems of visual configuration such as social distance and camera angle.

In terms of social distance or shot type, and camera angle, this, as noted, is a tight close shot taken at eye-level angle, therefore, eradicating all barriers and distances and creating a close almost personal rapport between the actor - the main represented participant - and what he/she is eying, on the one hand; and drawing in the process the interactive participants - you and me and the producer - into this long nostalgic silent dialogue, on the other, emphasizing personal connection and attachment. The effect of this is a sense of identification with the represented participant, and so the unity of purpose and destiny. As noted above, the viewers are drawn to view what the represented participant is viewing; to focus on what he/she is focusing; to share him/her his or her emotions and concerns, ambitions and aspirations. This has an effect of marshaling them and marching them towards one goal - Jerusalem!

A number of elements bring the compositional meaning into place. A closeup, the head almost takes up the whole frame, with the eyes/Jerusalem being foregrounded. This framing emphasizes the message and draws viewers towards the represented participant, creating intimacy. Further, the colours accentuate this message. Being largely black, and grey - dark colours - with the exception of the top part of the head/keffiyah representing unity in diversity, the colours are meant to call a spade a spade, to act as a reality check, as a wake-up call: 'Hey! This is not a dream. This is reality, bleak stark reality. Jerusalem is fettered and we have to do something about it!'

The image memorializes the religious and historical significance of Jerusalem to the world, and in so doing counteract the ongoing Israeli attempts at Judaizing it.

\subsection{The stone: Symbol of Intifada and resistance}

Aconceptual representation encoding a symbolic process where the stone-thrower in figure 6 - the only represented participant - symbolizes Palestinian resistance to Israeli occupation. It can also be said that the image depicts a narrative representation encoding a non-transactional action process. It is nontransactional because the goal is not seen. But here the missing participant is understood to be the Israeli occupation.

This composite visual was produced in 2012 by an anonymous international artist/designer. A symbol of the "stone revolution," of a "home denied," and "Palestine indestructible" — as intersemiotically stated in these three hashtags - 
this frontal eye-level medium shot visual of the stone-thrower is designed to stress the theme of resistance as symbolized by stone-throwing as being equal to one's existence - image subtitle.

From the point of view of composition, the represented participant - the Palestine flag-clad stone-thrower - is perceived as important given his central placement in the visual. Such importance is further accentuated through foregrounding. This draws attention to the importance of resistance in the process of liberation from colonial powers. The presence of framing in this composite visual which virtually divides the image into three parts stresses the theme of this multimodal text - resistance!

A celebration of resistance and the stone revolution, the image motivates not only Palestinians but also free citizens everywhere to "stand up" and "speak out" - as the textual element in the image indicates - against the ongoing Israeli campaign of ethnic cleansing, as the top heading or verbal element at top of the image states: SUPPORT PALESTINE, OPPOSE MASSACRE AT GAZA, GAZA NEED OUR VOICE NOW. Through equating resistance with existence, the image reconstructs the Israeli racial elimination of the indigenous population, which has never ceased. It began in 1948 and has continued ever since that first genocidal crime.

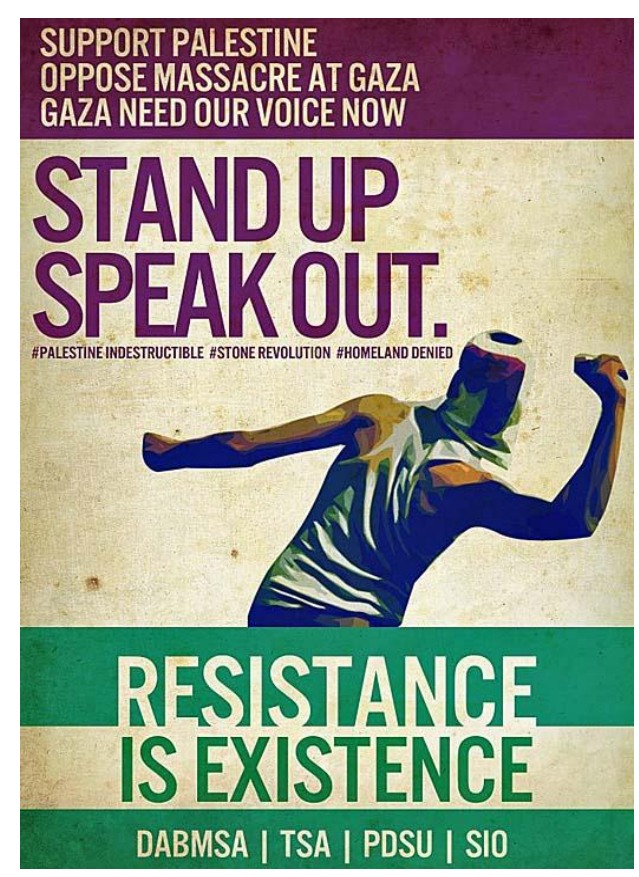

Figure 6. Stand up, Speak out! 


\section{Conclusions}

An important semiotic resource that involves social construction of reality along certain lines and hence identity, ideology and power, visual semiosis such as images can become emotive symbols for national themesand their memorial function, and so can act as a rallying cry or a mobilizing tool for resistance and renaissance. In the Palestinian context - that of ethnic cleansing, dispossession and forced displacement - the study has shown that such semiotic monumentsact as potent symbols of the national struggle of the Palestinian people for justice, liberation and self-determination. Thethemes represented in the analyzed visual representations in this social semiotic studycollectively shape the Palestinian consciousness and identity as they serve to reconstruct the ethnic cleansing of Palestine. They are a monument to the man-made Nakba or Israel's ethnic cleansing of Palestine.

These Nakba icons have pictured the atrocities of 1948 and so served in immortalizing and reconstructingthe Palestine Question as the plight of a people who have been driven out of their homeland. They have servedto keep the memory or trauma of ethnic cleansing afresh in the Palestinian collective consciousness. They have helped counteract Israeli attempts to abolish Palestine geographically, culturally, socially and politically from the Palestinian memory. These metonymic symbols have helped counteract such Israeli attempts at distortion, mystification and obliteration of the origins of the status quo. They have helped preserve the Palestinian national identity and the resurgence of Palestinian nationalism or national consciousness, making it difficult for Israelis to have the Palestinians' national, political and cultural identity and primordial, organic attachment to the land erased. They have defied the passage of time or that the Palestinians "may perhaps forget in one or two generations' time," as observed by Ben Gurion - one of the architects of Israel and the first Prime Minister and Minister of War.They have helped recreate historic Palestine through memory, thus making the prospect of return a living dream, and a political statement against the constant Israeli attempts at the Palestinian memoricide of the Nakba and erasure of historic Palestine from the "global public memory".

In a word, the study showed how certain visually represented themes and motifs such as the Nakba, the Right of Return, and resistance serve as a constant reminder of the ethnic cleansing of Palestine, and so play a central and significant sociopolitical role in shaping the Palestinian collective consciousness whether in diaspora or under occupation about a common past, present and future. It has shown how these visual representations - metonyms that have become symbols work to visually encode, solidify and perpetuate the Palestinian experience of deracination at the hands of Zionists (later Israelis) and the consequent and ongoing suffering, thus creating ongoing freshness to this protracted national trauma and social injustice. They lend the Palestine Question depth and solidity that defy oblivion and the settler colonialist systematic attempts at misrepresentation and memoricide. This serves to let this "Paradise Lost" and the 
increasing nostalgia for it remain engraved in the hearts, minds and memories of the Palestinian collective.

But most importantly, the study showed that through reconstructing the man-made "Nakba" - as an act of resistance against Israel's systematic attempts at memoricide and against the forgetfulness of history-visual resistance or visual activismcan help make Palestine-as-vision (as it exists today) Palestine-as-reality (tomorrow) - the afterlife effect of atrocity images.

\section{Aladdin Asseiqali, PhD}

Sultan Idris Education University (UPSI), Malaysia.

ORCID Number: 0000-0002-7687-5079

Email: assaiqeli@gmail.com

\section{References}

Assaiqeli, Aladdin. (2019). Palestine in UN Discourse: 'A critical discourse analysis'. Journal for the Study of English Linguistics, 8(1): 1-22. DOI: https://doi.org/10.5296/jsel.v8i1.15596

Assaiqeli, Aladdin. (2013). The linguistics of UN and Peace Discourse on the Palestine Question: A Critical Discourse Analysis. Germany: Scholars' Press. 
Alloul, Jaafar (2016). 'Signs of visual resistance in Palestine: Unsettling the settler-colonial matrix.' Middle East Critique, 25:1, 23-44.

DOI: $10.1080 / 19436149.2015 .1101874$

Abu Hashhash, Mahmoud. (2006). 'On the visual representation of martyrdom in Palestine.' Third

Text, 20:3-4, 391403, DOI: $10.1080 / 09528820600901008$

Amer, M. M. (2018). 'The iconography of a nation: National identity construction in Palestinian visual representations.'IUG Journal of Humanities Research, 28 (1), 1-24.

Abu Hatoum, Nayrouz. (2016). Framing Absence: Visuals of the Wall and the Vanishing Landscapes in Palestine.Unpublished Doctoral Dissertation. York University, Toronto, Ontario.

Baron, B. (1997). 'Nationalist iconography: Egypt as a woman'. In I. Gershoni and J. Jankowski (eds.), Rethinking Nationalism in the Arab Middle East. New York: Columbia University Press.

Bartelt, D. (1998). Both Sides of Peace: Israeli and Palestinian Political Poster Art. University of Washington Pr, Baltimore, Maryland, U.S.A.

Campbell, D. (2012). 'The iconography of famine.' In G. Batchen, M. Gidley, N. K. Miller, \& J. Prosser (eds.), Picturing Atrocity: Photography in Crisis, 79-92. London: Reaction Books.

Clarke, A.E. (2005). Situational Analysis: Grounded Theory After the Postmodern Turn. California: Sage Publications, Inc.

Cross, J. L. (2006). 'Icons as ideology.' In I. Lassen, J. Strunck and T. Vestergaard (eds.), Mediating Ideology in Text and Image: Ten Critical Studies. Amsterdam: John Benjamins.

Farrah, Mohammed. and Halahla, Nadia. 'Pronunciation problems among Palestinian English major students in Hebron University.'International Journal of Arabic-English Studies (IJAES), 20 (1), 203-226.

Economou, D. (2009). Photos in the News: appraisal analysis of visual semiosis and verbal-visual intersemiosis. Unpublished Doctoral Dissertation. University of Sydney, Australia.

Fairclough, N. (2001). Language and Power ( $2^{\text {nd }}$ ed.). London: Longman.

Gutwein, D. 2016. 'The politics of the Balfour Declaration: Nationalism, imperialism and the limits of Zionist-British cooperation.' Journal of Israeli History 35 (2): 117-152. https://doi.org/10.1080/13531042.2016.1244100.

Halliday, M.A.K. (1975). Learning How to Mean: Explorations in the Development of Language. London: Edward Arnold.

Halliday, M.A.K. (1978). Language as Social Semiotic: the Social Interpretation of Language and Meaning. London: EdwardArnold.

Halliday, M. A. K. (1994). An Introduction to Functional Grammar ( $2^{\text {rd }}$ ed.). London: Edward Arnold.

Halliday, M. A. K. and Matthiessen, C. M. I. M. (2004). An Introduction to Functional Grammar ( $3^{\text {rd }}$ ed.). London: Arnold.

Jay, M. (2002). 'That visual turn: The advent of visual culture.' Journal of Visual Culture 1 (1):87-92. 
Kress, G. and van Leeuwen, T. (1990). Reading Images. Geelong, Victoria: Deakin University Press.

Kress, G. and van Leeuwen, T. ([1996]2006). Reading Images: The Grammar of Visual Design ( $2^{\text {nd }}$ ed.). London: Routledge.

Krzyżanowski, M. 2016. 'Recontextualisation of neoliberalism and the increasingly conceptual nature of discourse: Challenges for critical discourse studies.'Discourse \& Society 27(3): 308-321. https://doi.org/10.1177/0957926516630901.

Meyer, C.F. (2009). Introducing English Linguistics. New York: Cambridge University Press.

Pappe, I. (2006). The Ethnic Cleansing of Palestine. Oxford: Oneworld Publications.

Ramamurthy, A. (2016). 'Contesting the Visualisation of Gaza.' Photographies, 9 (1), 31-50.

Ravelli, L., Adami, E., Boeriis, M., Veloso, F.O., and Wildfeuer, J. (2018). 'Visual communication: mobilizing perspectives.'Visual Communication, 17(4), 397-405.

Royce, T.D. (1998). 'Synergy on the page: Exploring intersemiotic complementarity in page-based multimodal text.'JASFL Occasional Papers, 1 (1), 25-49.

Shihade, Magid. (2012). 'Settler colonialism and conflict: The Israeli state and its Palestinian subjects.'Settler Colonial Studies, 2(1): 108-123. https://doi.org/10.1080/2201473X.2012.10648828

Simpson, P. (1993). Language, Ideology and Point of View. London and New York: Routledge.

Titscher, S., Meyer, M., Vetter, E., and Wodak, R. (2000). Methods of Text and Discourse Analysis. London: Sage Publications Ltd.

Thuy, T.T.H. (2017). 'Reading images: The grammar of visual design'. VNU Journal of Foreign Studies, 33 (2), 164-168.

Van Dijk, T.A. (2008). Discourse and Power. Basingstoke: Palgrave.

Walsh, D.J. (2009). Teaching the Formative History of Political Zionism (18971947) through Poster Art: A New Curriculum Model for the American High School. https://www.slideshare.net/PalestinePosterProject/new-curriculum (Retrieved on October $16^{\text {th }} 2018$ ).

White, J.V. (1982). Editing by Design (2 ${ }^{\text {nd }}$ ed.). New York: R.R. Bowker Company.

Wodak, R., and Meyer, M. (2009). 'Critical discourse analysis: History, agenda, theory and methodology.' In R. Wodak, \& M. Meyer (eds.), Methods of Critical Discourse Analysis ( ${ }^{\text {nd }}$ edn.), 1-33. London: Sage. 
Young, R.F. (2009). Discursive Practice in Language Learning and Teaching. Wiley-Blackwell.

\section{Endnote}

${ }^{1}$ https://www.palestineposterproject.org/

${ }^{2}$ There is actually a significant Quranic study by Bassam Jarrar in the early 1990s that predicts that the year 2022 could be the year of the liberation of Palestine and the end of Zionism/Israel. 